\title{
Selvmord i psykiatriske døgninstitusjoner: reaksjoner og oppfølging blant personalet
}

\author{
Ved $\mathrm{H}$ ans Lander og Ingrid N esje
}

\section{Mange helsearbeidere i psykiatriske institusjoner opplever å miste en pasient i selvmord under innleggelsen. Dette kan skape sterke reaksjoner blant personalet, iblant også på lengre sikt. Samtidig som personalet skal håndtere sine egne reaksjoner, skal de ivareta de etterlatte i pasientens familie. Hvordan personalet reagerer og hva som anbefales som god hjelp og støtte for dem, vil vaere fokus i denne artikkelen.}

\section{Bakgrunn}

Psykiatriske pasienter utgjør en risikogruppe for å ta sitt eget liv. Til tross for at det ikke finnes sikre tall, regner man i dag med at det årlig skjer 40-50 selvmord blant pasienter innlagt i psykiatriske institusjoner i N orge, noe som utgjør ca hvert tiende selvmord $\mathrm{i}$ landet. Det har fra 1955 og frem til i dag funnet sted en kontinuerlig økning i antall selvmord i psykiatriske sykehus i N orge (Retterstøl, 1995). Et selvmord får store konsekvenser for familie og venner, men det påvirker også fagpersoner. Internasjonale undersøkelser viser at så mye som halvparten av alle psykiatere har mistet en pasient i sel vmord ( $H$ endin et al., 2000). G jennom vårt arbeid har vi møtt personale fra ulike yrkesgrupper som har opplevd å miste en eller flere pasienter i selvmord. Den oppfølgingen de beskriver er varierende, preget av tilfeldigheter og noen ganger fraværende. Vi har ikke funnet noen skriftlige rutiner for oppfølging av personale ved de institusjonene vi har hatt kontakt med.

\section{Reaksjoner}

$M$ ange studier viser at helsearbeidere kan ha liknende reaksjoner som familiemedlemmer og venner etter å ha mistet en pasient i selvmord. Forskning knyttet til det å miste en pasient i selvmord beskriver oftest terapeuters reaksjoner.

Vanlige umiddel bare reaksjoner er sjokk, tristhet, skyldfølelse og sinne overfor den avdøde (Clark \& G oldney, 2000; H endin et al., 2000; Clark, 2001). Disse forskerne beskriver også reaksjoner hos terapeuter som følelse av et personlig tap, skam,

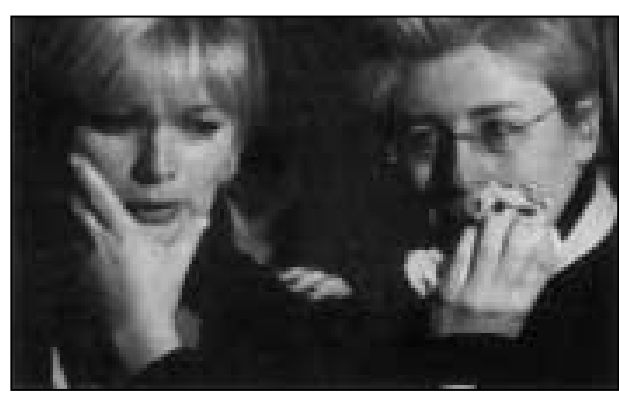

mistillit til egen faglighet og dyktighet, men også lettelse. Clark og G oldney (2000) beskriver videre forekomst av varige personlige ettervirkninger som fysisk sykdom, depresjon, angst og problemer i mellommenneskelige og profesjonelle relasjoner. Distansering fra pasienter og kollegaer eller det motsatte, overinvolvering, er beskrevet. I tillegg kan en finne redsel for sinne fra familien til den avdøde eller for trussel om rettssak, mye fravær fra jobb og også skifte av jobb.

Det er få andre hendel ser som kan fremkalle en slik opplevelse av å ha sviktet og gi opphav til skyldfølelse hos hjelperen, som en pasients selvmord (Lloyd, 1995). Lloyd fremhever at selvmord nesten alltid blir betraktet som en hendelse vi skulle vært i stand til å forebygge. Vi kunne ha gjort en bedre risikovurdering av den selvmordsnære pasienten, vi kunne tatt hans suicidale signaler mer alvorlig og tatt bedre kontroll over situasjonen.

K vinnelige terapeuter ser ut til å føle mer skyld og skam, de tviler mer på egen faglighet og oppsøker oftere hjelp. M an finner ingen forskjell i reaksjoner etter hvor lang erfaring eller hvilket yrke behandleren har (G rad et al., 1997).

En personalgruppe vil i etterkant av et selvmord kunne oppleve at pasientene blir ekstra sårbare. Et selvmord kan aktivere egen selvmordsproblematikk hos medpasienter og skape økt utrygghet (Kaye \& Soreff, 1991). Pasientene kan oppleve at personalet har sviktet, og det blir viktig å iverksette tiltak som kan imøtekomme utryggheten.

Enkelte beskriver en prosess hvor man Iærer av hendelsen og dermed får økt sin personlige og profesjonelle innsikt. Dersom man undertrykker sine følelser og ikke får gitt uttrykk for sorgen og reaksjonene, kan det vanskeliggjøre læring (Clark \& Goldney, 2000). Dette kan igjen gjøre det vanskelig å ta seg av oppgavene man har ansvar for. Dilemmaet med å ivareta egne reaksjoner samtidig med å skulle tilrettelegge oppføl ging for familien, medpasienter og eget personale, opplever mange som problematisk.

De ulike reaksjonene som er beskrevet her, er knyttet til tapet, men også til hendelsen som et traume. Traumatiske tap er forbundet med dødsfall knyttet til en eller flere av følgen de kriterier: brå og uventet død, død ledsaget av sterke sanseinntrykk, altfor tidlig død eller flere dødsfall som skjer samtidig (Dyregrov, 2003). I noen tilfeller kan den traumatiske komponenten ved tapet medføre sterke reaksjoner. Personale som finner den døde personen, som direkte deltar i eventuelle gjenopplivingsforsøk eller i annen håndtering av den avdøde, blir iblant utsatt for overveldende sanseinntrykk. Dette kan resultere i plagsomt påtrengende tanker og minnebilder, iblant i form av "flash-back" (personen opplever plutselig å være i situasjonen) eller gjentatte mareritt. Disse reaksjonene rubriseres som gjenopplevelsessymptomer. Sterke minnebilder kan bidra til konsentrasjonsvansker, angst og søvn problemer. A ndre symptomer slik som kroppslig uro og irritabilitet tyder på økt alarmberedskap og aktivering av nervesystemet. Da er personene i en tilstand av overdreven vaktsomhet og økt mental beredskap, eller reagerer med skvettenhet på noe som kan forbindes med det som skjedde. Vanlig er også unngåel se av det som minner om dødsfallet. En unngår å slippe til følelser og tanker, eller unngår stedet for dødsfallet eller steder og situasjoner som kan minne om hendelsen (Dyregrov, 2002; Dyregrov, 2003; Senter for K risepsykologi, 2003).

\section{Oppfølging}

G rad (1999) finner i sin studie at flertallet av det spurte personalet svarte at det å snakke med noen av sine nære hadde vært til stor hjelp (56\%). A arbeide videre som vanlig hjalp ytterligere $16 \%$, og noen få hadde følt det som en hjelp å prøve å finne ut årsakene til selvmordet ( $5 \%$ ). V idere beskrives det å få snakke om egne følelser og refleksjoner sammen 


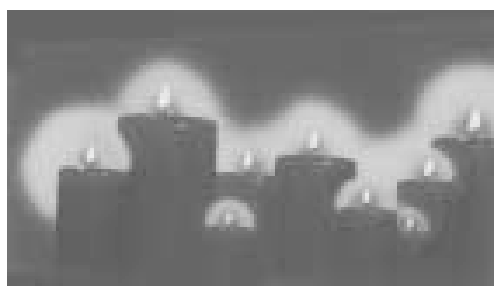

med en annen person eller i gruppe som en av flere måter å hjelpe terapeuter på. Dette bør skje sammen med noen som har erfart det samme, eller som har erkjent at de kan komme til å oppleve det.

G itlin (1999) gjennomgår en case hvor en psykiater opplevde at en pasient som gikk i individualterapi, tok sitt eget liv. $\mathrm{H}$ an beskriver tre punkter som han anser som viktige for å kunne mestre situasjonen best mulig. Disse er å unngå å isolere seg, arbeide konstruktivt med temaet og å ta i bruk spesielle kognitive tenkemåter. $\mathrm{H}$ er nevner han at det er viktig å ta det faktum inn over seg at selvmord er en mulig utgang ved alvorlig psykisk lidelse. Det er viktig å erkjenne at når en pasient ikke lenger er i tvil, kan selvmord være uunngåelig. I denne sammenhengen nevner $\mathrm{G}$ itlin at det ikke finnes presise måleinstrumenter for å predikere selvmordsfare.

Personalet vil ha ulike behov for oppfølging avhengig av relasjonen til pasienten. De som er ansvarlige for behandlingen, er i en særstilling. Det er grunn til à mene at de er mer utsatt for de mest langvarige reaksjonene, med skyld, sorg, tvil på egen kompetanse m.m.

Den eller de som først finner en pasient etter et selvmord, vil være utsatt for en rystende og traumatisk opplevelse. Det å finne en død person gir sterke sanseinntrykk som kan innbefatte både lyd, lukt, hørsel, fysisk berøring og synsinntrykk. De av personalet som opplever dette, vil ha behov for spesiell oppfølging (M ehlum, 2003; W eisæth, 2003). I tillegg til støtte fra ledelse og kollegaer er det anbefalt umiddel bar utsnakking og en senere psykologisk debriefing. Det er utviklet spesielle prosedyrer for en debriefing, og den skal ledes av personale som har fătt egen opplæring i dette. D en psykologiske debriefingen holdes vanligvis 1-3 døgn etter hendelsen. Selv om effekten av psykologisk debriefing er omdiskutert, er det mange klinikeres erfaring at den er verdifull. Vi oppfatter det som et velbegrunnet tiltak overfor (innsats)-personale (W eisæth, 2000; 2003). Videre må man være klar over at det for noen kan være behov for en forlenget oppfølging fordi sterke reaksjoner knyttet til den traumatiske opplevelsen forekommer (Dyregrov, 2002; M ehlum, 2003; W ei sæth, 2003).
Kaye og Soreff (1991) beskriver de oppgavene som påhviler den ansvarlige psykiater etter et selvmord, og hvordan personalet bør ivaretas. Det er viktig at hele personalet blir orientert om dødsfallet snarest mulig. Dette gjøres best ved felles samling av personalgruppen. Dette må gjentas ved behov slik at hele gruppen blir informert. Det skal tilrettelegges for at kollegene kan gi hverandre støtte, og for at en får mulighet til å ventilere følelser. O fte kan det være behov for flere møter for å gjennomarbeide det som har skjedd. Dette kan skje både i gruppe og som personlig veiledning. Kaye og Soreff poengterer at en som behandler ikke skal bli stående alene med mye ansvar etter et selvmord blant en av sine pasienter. Det bør raskt opprettes en kontakt med en mer erfaren kollega som kan ha en støttende rolle de første dagene etter selvmordet.

I tillegg til det som er nevnt ovenfor, viser Bartels (1987) til at den uformelle kollegastøtten har blitt beskrevet som den viktigste støtten i undersøkel ser, og derfor ikke må undervurderes. $\mathrm{H}$ an konkluderer med at en dårlig ivaretakelse av personalets reaksjoner og den faglige utfordringen ved dødsfallet kan lede til demoralisering og depressive tanker i personalgruppen.

Ritualer er viktige. M innestund/samling bør holdes for personalet og medpasienter innen to uker etter dødsfallet (Bartels, 1987). Deltakelse i begravelse eller å vise oppmerksomhet via blomster eller kort til familien anses også som verdifullt for berørt personale. Dette er en måte å bearbeide egne følel ser på samtidig som det gir en anledning til å vise respekt for den avdøde og ta farvel. Det anbefales å gjennomføre en strukturert selvmordsgjennomgang (psykologisk autopsi). M ålsettingen er å dra lærdom av det som har skjedd og skape forbedringer i sin praksis. Dette fremmer åpen het om temaet og er med på å øke kompetansen hos de ansatte (Kaye \& Soreff, 1991; Haga, 1990). Tidspunktet for en slik selvmordsgjennomgang bør utsettes til personalets emosjonelle behov er godt nok ivaretatt (Bartels, 1987). Dette vil variere, men betyr som regel noen uker etter selvmordet. G jennomgangen bør ledes av en person utenfor den avdeling/enhet der selvmordet har skjedd.
M ålet er å skape større innsikt og forståelse for hva som skjedde og mulige årsaker. H er må en prøve å finne en vei mellom to ytterpunkter: På den ene siden at de selvmord som skjer, er uunngåelige og ikke kan forhindres. På den andre siden at alle selvmord skjer fordi en gjør faglige feil i vurderinger og diagnostisering, eller fordi det er svikt i empatisk støtte (Bartels, 1987). Selv om skyld ikke skal stå i fokus, er det viktig heller ikke å bagatellisere eller ignorere det som kunne vært gjort annerledes. M ålet er å dra lærdom av det inntrufne. En må da tydeliggjøre realistiske begrensninger i behandling og omsorg og i å forutse selvmord. En kan ikke si kre seg fullstendig mot nye selvmord. I steden må en ha en åpenhet og være forberedt på at det kan skje igjen. D et er vist at en selvmordsgjennomgang kan være en betydelig stressfaktor og skape dårlig faglig selvtillit hos behandlere om den ikke utføres på en adekvat måte ( $H$ endin et al., 2000).

Institusjoner som jevnlig er i kontakt med selvmordsnære pasienter, har et ansvar for å hjelpe den enkelte medarbeider til å bearbeide et selvmord. Slik hjelp og støtte skal aktivt tilbys personalet som er berørt (Kaye \& Soreff, 1991; de la C our 2000; M ehlum 2003). D et bør settes opp skriftlige retningslinjer for dette ( $M$ ichel et al., 1997; Grad, 1999). Det å ha en slik prosedyre er, foruten å sikre rutinemessig oppfølging, med på å bevisstgjøre behandlere på det faktum at pasienter kan ta sitt eget liv. M ichel og medarbeidere (1997) sier at en allerede i helseutdanningene må forberedes på at arbeid med psykiatriske pasienter kan bety å miste noen $\mathrm{i}$ selvmord.

\section{Avslutning}

Reaksjoner og anbefalte oppfølgingstiltak blant psykiatrisk personale er til en viss grad beskrevet i forskningslitteraturen. Det er i stor grad samsvar mellom det ulike forskere og klinikere beskriver som verdifull og hensiktsmessig oppfølging. Personale som blir berørt av et selvmord, bør møtes med en aktiv og oppsøkende holdning. Institusjonen bør ha nedfelte rutiner for hvordan oppfølgingen skal gis, slik at tiltak kan iverksettes auto- 
matisk. Ledelsen i den enkelte psykiatriske enhet har her en nøkkelrolle.

U nder oppfølgingen av personalet bør de ansatte få anledning til å gi uttrykk for følelser og gi støtte til hverandre, og en bør unngå at noen blir ståen de alene med mye ansvar. $\mathrm{N}$ år de følel sesmessige reaksjonene har blitt tatt hånd om, vil en kunne gå videre i å dra Iærdom av det som har skjedd. D ette kan til rettel egges ved å gj ennomføre en selvmordsgjennomgang. H ovedformålet med å gi oppføl ging til personalet etter et selvmord er å motvirke redusert arbeids- og livskvalitet og å forebygge langtidsskader. D essuten er det et mål at personalet kan fortsette å arbeide hensiktsmessig med mennesker med selvmordsproblematikk. En god bearbeiding kan føre til et mer realistisk syn på faglige begrensninger og forsoning med seg selv.

Det er viktig at psykiatriske institusjoner har fokus både på selvmordsforebygging og på nødvendige oppføl gingstiltak etter en pasients selvmord. Personalet er her en gruppe som må vies tilstrekkelig oppmerksomhet. De kan ofte ha tanker om skyld og ansvar knyttet til selvmordet, med ubesvarte spørsmål om noe kunne vært gjort annerledes. I tillegg kommer ansvaret for at de etterlatte og annet personale blir ivaretatt, samt egne behov for støtte. På bakgrunn av våre samtaler med fagpersoner innen psykiatrien har vi stilt oss spørsmål om den kunnskapen man har om reaksjoner og behov for oppfølging hos personalet ikke blir tatt tilstrekkelig i bruk.

\section{Referanser}

Bartels, S. J. ( 1987). T he aftermath of suicide on the psychiatric inpatient unit. G eneral $H$ ospital Psychiatry, 9, 189-197.

Clark, S. (2001). B ereavement after suicide $\mathrm{H}$ ow far have we come and where do we go from here? C risis, 22, 102-108.

Clark, S. C., \& Goldney, R. D. (2000). T he impact of suicide on relatives and friends. I K. H awton $\& \mathrm{~K}$. van $\mathrm{H}$ eeringen (red.), The international handbook of suicide and attempted suicide (side 467-484). Chichester: John Wiley \& Sons.

de la C our, J. (2000). Suicide in the ward setting. $\mathrm{N}$ ursing Times, 96 (40), 39-40.

Dyregrov, A . (2002). Katastrofepsykologi

(2. utg.). Bergen: Fagbokforlaget.
Dyregrov, K. (2003). U nges sorg ved traumatiske tap. Foredrag ved konferanse om psykisk hel se blant barn og unge. Rådet for psykisk helse. Lillestrøm, mars.

Gitlin, M. J. (1999). A psychiatrist's reaction to a patient's suicide. A merican Journal of Psychiatry,156, 1630-1634.

G rad, O. (1999). H elsepersonell som etterlatte ved selvmord. Suicidologi, 4 (3), 16-17.

Grad, O ., Zavasnik, A ., \& G roleger, U. (1997). Suicide of a patient: $G$ ender differences in bereavement reactions of therapists. Suicide and Life-Threatening Behavior, 27, 379-386.

H aga, E. (1990). Selvmordsgjennomgang psykologisk autopsi. Tidsskrift for Den norske lægeforening, 110, 3643-3644.

H endin, H., Lipschitz, A ., M al tsberger, J. T., Pollinger Haas, A ., \& W ynecoop, S. (2000).

T herapists' reactions to patients' suicides. A merican Journal of Psychiatry, 157, 2022-2027.

Kaye, N. S., \& Soreff, S. M . (1991). T he psychiatrist's role, responses, and responsibilities when a patient commits suicide. The A merican Journal of Psychiatry, 148, 739-743.

Lander, H, \& N esje, I. (2004). Selvmord i psykiatriske døgninstitusjoner: $R$ eaksjoner og oppfølging av etterlatte i familien og personalet. Skriftserie nr 8, Psykiatrisk forsknings- og utviklingsavdeling, U niversitetssykehuset N ord-N orge, Tromsø

Lloyd, G. G . (1995). Suicide in hospital:

$\mathrm{G}$ uidelines for prevention. Journal of Royal Society of M edicine, 88, 344-346.

M ehlum, L. (2003). Selvmordsgjennomgang og personalstøtte. Forelesning ved Videreutdanning i sel vmordsforebyggende arbeid. U niversitetet i 0 slo. 0 slo, mai.

M ichel, K., A rmson, S., Fleming, G ., R osenbauer, C., \& Takahashi, Y. (1997). A fter suicide: W ho counsels the therapist? Report from a workshop at the 29th Congress of the IA SP. C risis, 18, 128139

Retterstøl, N . (1995). Selvmord i psykiatriske institusjoner. I N. Retterstøl, Sel vmord. (5. utg.) (side 148-163) O slo: U niversitetsforlaget.

Senter for Krisepsykologi ( 2003). W ebsider på http://www.kri sepsyk.no. Bergen: Senter for Krisepsykologi, august.

W eisæth, L. (2000). B riefing and debriefing: $G$ roup psychological interventions in acute stressor situations. I B. Raphael \& J. P. W ilson (red.), Psychological debriefing. Theory, practice and evidence (side 43-57). C ambridge: C ambridge U niversity Press.

W eisæth, L. (2003). H åndtering av den døde ved selvmord. Forelesning ved Videreutdanning i selvmordsforebyggen de arbeid. U niversitetet i 0 slo. Oslo, mai.
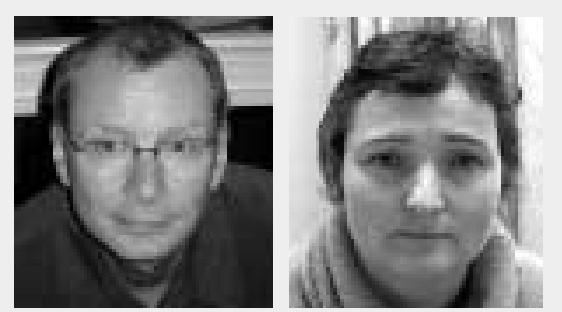

H ans L ander er psykiatrisk sykepleier og leder av Senter for forebygging av selvmord i N ord-N orge ved U niversitetssykehuset N ord-N orge, Tromsø.

Ingrid N esje er psykiatrisk sykepleier og fagkonsulent samme sted.

Begge har de senere årene arbeidet med problematikk knyttet til selvmordsforebygging innenfor det psykiske helsevernet. De har også vært opptatte av situasjonen til etterlatte etter selvmord, inkludert familiens og personalets situasjon etter selvmord i psykiatrien.

A rtikkelen er basert på en prosjektoppgave ved Videreutdanning i selvmordsforebyggen de arbeid, U niversitetet i O slo, høsten 2003. O ppgavens hovedfokus er familien. $\mathrm{H}$ er presenteres et utdrag av det som er beskrevet om personal et.

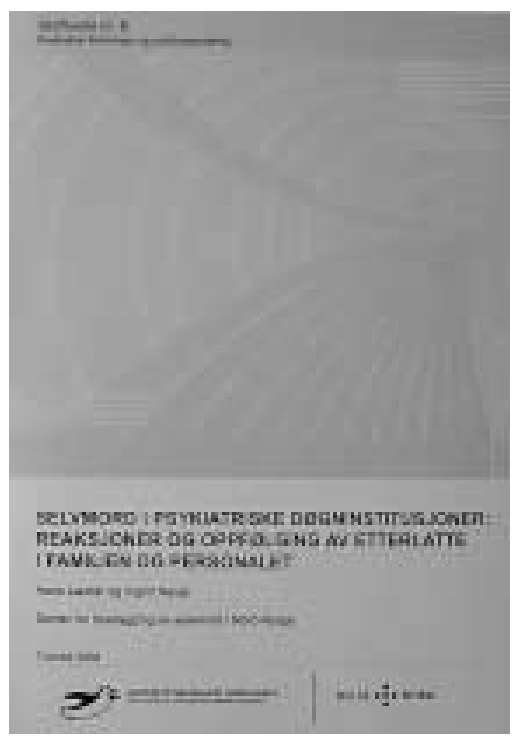

Lander, H, \& N esje, I. (2004). Selvmord i psykiatriske døgninstitusjoner: R eaksjoner og oppfølging av etterlatte $\mathrm{i}$ familien og personalet. Skriftserie nr 8, Psykiatrisk forsknings- og utviklingsavdeling, U niversitetssykehuset $\mathrm{N}$ ord$\mathrm{N}$ orge, Tromsø.

O ppgaven er tilgjengelig på www.unn.no/selvmord Den kan også bestilles på e-post: selvmord@unn.no 